\title{
POTENSI TEMPE (RHYZOPUS.SP) SEBAGAI SUMBER PHYTOESTROGENS UNTUK MENGAKTIFKAN DAN MENCAPAI SEL STEM DALAM PERBAIKAN LENSA KATARAK DAN PERBAIKAN METANOLIK DARI EKSTRAK GARLIC (ALLIUM SATIVUM) SEBAGAI TERAPI TERAPI DALAM KATAK DIABETIK
}

\author{
Ihsan Otriami, ${ }^{1}$ Devin Mahendika, ${ }^{1}$ Dio Jainata, ${ }^{1}$ \\ ${ }^{1}$ Medical Education Study Program, Faculty of Medicine, Andalas University, Padang \\ ihsanotriami@gmail.com
}

\begin{abstract}
Cataracts are turbidity lenses that are normally transparent and light is passed through to the retina, which is caused by various things resulting in impaired vision. One of the causes of cataract is diabetes mellitus which manifests clinically as hyperglycemia. Various therapies have been developed to deal with cataracts. However, the therapy is a definitive form of surgery which causes long-term complications in the form of blindness. One of the therapeutic modalities developed today is stem cell therapy. Stem cells are undifferentiated cells and have high potential to become other cells. Stem cells can differentiate to repair damaged lentic capsules and the formation of subepithelial lamellar fibers. Stem cells proliferate and migrate will be assisted by estrogen. However, the use of estrogen often causes bad side effects for the body. So, estrogen replacement is needed which has the same effect but does not produce side effects.

Tempe is a typical Indonesian food that has isoflavonoid content. Isoflavonoids are able to function as phytoestrogens in the human body and have the same function as 17ß-estradiol. In stem cells, phytoestrogens will play a role in activating paracrine actin (Akt) and stromal cell derived-1 (SDF-1) signals. Phytoestrogens will accelerate the rate of mesenchymal stem cell (MSC) / induced pluripotential stem cell (iPSC) and bind to the right receptors, so as to increase the work effectiveness of stem cells. Meanwhile, in diabetic cataract conditions the potential for garlic methanolic has recently been developed in relation to antioxidant effects, effective hypoglycemic and scavenging oxidative stress factors such as $\mathrm{H}_{2} \mathrm{O}_{2}$ and decreasing protein fraction in the lens due to protein insolubility.
\end{abstract}

Keywords $\quad$ : Tempe, Stem Cell, Phytoestrogens, Garlic, and Metanolic.

\begin{abstract}
Abstrak
Katarak merupakan kekeruhan lensa yang normalnya transparan dan dilalui cahaya ke retina, yang disebabkan berbagai hal sehingga terjadi kerusakan penglihatan. Penyebab katarak salah satunya adalah diabetes melitus yang bermanifestasi klinis berupa hiperglikemia. Beragam terapi telah dikembangkan untuk mengatasi penyakit katarak. Namun, terapi yang dilakukan merupakan terapi definitif berupa pembedahan yang menimbulkan komplikasi jangka panjang berupa kebutaan. Salah satu modalitas terapi yang dikembangkan saat ini adalah terapi sel punca. Sel punca merupakan sel yang belum berdiferensiasi dan memiliki potensi tinggi menjadi sel yang lain. Sel punca dapat berdiferensiasi memperbaiki kapsula lentis yang rusak dan pembentukan serat-serat lamelar subepitel. Sel punca berproliferasi dan bermigrasi akan dibantu oleh estrogen. Namun, penggunaan estrogen sering menimbulkan efek samping yang buruk bagi tubuh. Sehingga, diperlukan pengganti estrogen yang memiliki efek yang sama tetapi tidak menghasilkan efek samping.

Tempe merupakan makanan khas Indonesia yang mempunyai kandungan isoflavonoid. Isoflavonoid mampu berfungsi sebagai fitoestrogen di dalam tubuh manusia dan memiliki fungsi yang sama persis dengan 17ßestradiol. Pada sel punca, fitoestrogen akan berperan mengaktivasi sinyal parakrin aktin (Akt) dan stromal cell derived-1 (SDF-1). Fitoestrogen akan mempercepat laju mesenchymal stem cell (MSC)/ induced pluripotential stem cell (iPSC) dan berikatan dengan reseptor yang tepat, sehingga mampu meningkatkan efektivitas kerja dari sel punca. Sementara itu, pada keadaan katarak diabetik potensi metanolik bawang putih akhir-akhir ini telah dikembangkan terkait dengan efek antioksidan, hipoglikemik yang efektif dan memulung faktor stres oksidatif seperti $\mathrm{H}_{2} \mathrm{O}_{2}$ dan menurunkan fraksi protein pada lensa akibat insolubilitas protein.
\end{abstract}

Kata kunci $\quad$ : Tempe, Stem Cell, Fitoestrogen, Bawang Putih, dan Metanolik. 


\section{PENDAHULUAN}

Sebuah novel yang cukup memprihatinkan bagi keadaan Indonesia dewasa ini, tepat pada 7 April lalu sebagai Peringatan Hari Kesehatan Dunia menjadi catatan bahwa indikator kesehatan Indonesia masih memiliki rapor merah disamping keadaan Indonesia yang saat ini menjadi titel pasar penyakit, salah satunya penyakit Mata. ${ }^{1}$

World Sight Day atau Peringatan Hari Penglihatan Dunia, 12 Oktober setiap tahunnya yang bertujuan untuk meningkatkan kepedulian terhadap kebutaan dan gangguan penglihatan sebagai masalah global. Peringatan Hari Pengelihatan ini menjadi titik tolak utama jangka panjang dalam mencegah penyebaab kebutaan pada mata. Berbicara tentang katarak, Katarak merupakan penyebab utama kebutaan di Indonesia. ${ }^{2}$

Katarak adalah setiap kekeruhan pada lensa mata. Beberapa studi cross-sectional di berbagai negara melaporkan prevalensi katarak sebesar $50 \%$ terdapat pada individu berusia 65-74 tahun dan prevalensi ini meningkat hingga $70 \%$ pada individu di atas 75 tahun. Katarak merupakan penyebab kedua gangguan penglihatan terbanyak di seluruh dunia dengan prevalensi 33\% setelah gangguan refraksi yang tidak terkoreksi dengan prevalensi $42 \%{ }^{3,4,5}$

Persatuan Dokter Spesialis Mata Indonesia (PERDAMI) mendata, penderita katarak di Indonesia cukup tinggi, pada tahun 2012 mencapai 2,4 juta orang dengan pertambahan sekitar 240 ribu pertahun. ${ }^{6}$ Untuk itu, organisasi ini menilai penyakit katarak perlu mendapat penanganan prioritas dari pemerintah, dimana penderita sudah melebihi angka $1 \%$ dari jumlah penduduk yang ada. ${ }^{7}$ Indonesia menjadi negara yang berpotensi memiliki penderita katarak cukup tinggi. Walaupun katarak umumnya menyerang usia lanjut, namun prevalensi katarak di Indonesia $16-20 \%$ terjadi pada usia (40-54 tahun $)^{8}$, yang menurut kriteria Biro Pusat Statistik (BPS) termasuk dalam kelompok usia produktif. Prevalensi katarak di Indonesia berdasarkan Laporan Riset Kesehatan Dasar (Riskesdas) 2013, yaitu sebesar 1,8 \%. ${ }^{9}$ Sementara itu, untuk katarak diabetik diperkirakan pada tahun 2030 akan mencapai angka 21,3 juta kasus. ${ }^{10}$

Secara umum, katarak disebabkan oleh usia lanjut. Usia lanjut akan berdampak pada peningkatan gangguan penglihatan secara langsung yakni katarak dan secara tidak langsung yakni retinopati dan katarak diabetik, seterusnya paparan sinar ultraviolet yang terlalu lama dari sinar matahari, trauma okular yang pernah dialami atau operasi intraokular, penyakit okular, misalnya radang, glaukoma dan penyakit sistemik pada diabetes melitus. ${ }^{11}$

Sementara, pada katarak diabetik beberapa keadaan seperti hiperglikemia menjadi faktor risiko utama pencetus katarak diabetik sehingga terdapat penimbunan sorbitol dan fruktosa di dalam lensa. Penderita katarak akan mengalami pemudaran dan peredupan penglihatan secara progresif, pemudaran warna, penglihatan ganda. ${ }^{12}$ Secara khusus, pada katarak diabetik sering terlihat kekeruhan tebaran salju subkapsular yang sebagian jernih dengan pengobatan. ${ }^{13}$ Adapun untuk menegakkan diagnosis pada penderita katarak ataupun katarak diabetik perlu dilakukan uji ketajaman visual, pengukuran tekanan intraokular, dan funduskopi. ${ }^{10,14}$

Saat ini untuk mengatasi katarak, operasi dan pembedahan menjadi tujuan definitif pengobatan katarak. Namun, terapi definitif yang diberikan saat ini banyak menimbulkan komplikasi yang akan menambah beban negara Indonesia. Komplikasi setelah operasi sering ditemukan seperti, perdarahan, glaukoma, ablasio retina, edema makula, dekompensasi kornea. ${ }^{10}$

Saat ini telah dikembangkan terapi etnobotani bersifat fitoestrogen yang terdapat pada tempe. Fitoestrogen memiliki fungsi yang sama dengan $17 \beta-$ estradiol. ${ }^{15}$ Pada sel punca, fitoestrogen 
akan berperan mengaktivasi sinyal parakrin aktin (Akt) dan stromal cell denved factor-1 (SDF-1). Fitoestrogen akan mempercepat laju mesenchymal stem cell (MSC) atau induced pluripotential stem cell dan berikatan dengan reseptor yang tepat, sehingga mampu meningkatkan efektivitas kerja dari sel punca. ${ }^{16}$ Selain penggunaan tempe sebagai lens repair akibat opasitas karena katarak, pengembangan tumbuhan herbal lainnya seperti bawang putih saat ini sedang dikembangkan untuk mengatasi kejadian katarak diabetik yang memiliki fungsi signifikan sebagai anti-hiperglikemia dan pemulung stres oksidatif sebagai faktor utama pencetus terjadinya katarak diabetik. ${ }^{17,18}$ Sehingga penulis tertarik untuk menulis literature review yang berjudul "Potensi Tempe (Rhyzopus.sp) sebagai Sumber Fitoestrogen untuk Mengaktivasi dan Mempercepat Sel Punca pada Lens Repair Katarak dan Kandungan Metanolik Ekstrak Bawang Putih (Allium sativum) sebagai Terapi Mutakhir pada Katarak Diabetik."

\section{METODE}

Penulisan karya ilmiah dan tinjauan pustaka ini menggunakan metode studi pustaka yang didasarkan atas hasil studi terhadap berbagai literatur yang telah teruji validitasnya, berhubungan satu sama lain, serta mendukung uraian atau analisis pembahasan. Studi pustaka (literature review) menggunakan database pada www.pubmed.com dan scholar.google.com dengan menggunakan kata kunci: fitoestrogen, tempe, katarak, stem cell, bawang putih, metanolik, dan katarak diabetik. Metode studi pustaka hanya diperuntukkan kepada jurnal ilmiah yang menggunakan bahasa Inggris, bahasa Indonesia, dan memiliki abstrak dalam jurnal ilmiah tersebut. Judul dan abstrak akan menjalani proses pemindaian (scanning) untuk melakukan eksklusi jurnal ilmiah yang bersifat tidak relevan terhadap kata kunci pada pernyataan sebelumnya. Setelah melewati proses eksklusi, maka jurnal ilmiah akan dibaca secara keseluruhan untuk menjalani proses inklusi berdasarkan kriteria yang telah ditetapkan oleh penulis. Selanjutnya, daftar pustaka pada jurnal ilmiah yang telah berhasil melewati kriteria inklusi dan eksklusi akan menjalani proses pemindaian kembali untuk mengetahui adanya publikasi tambahan mengenai fitoestrogen, tempe, katarak, stem cell, bawang putih, metanolik, dan katarak diabetik .

Dalam tinjauan pustaka ini, kami menggunakan seluruh jurnal ilmiah yang membahas mengenai analisis manfaat, mekanisme kerja, fitur klinis dan efek terapi pada tempe dan bawang putih. Jurnal ilmiah akan menjalani proses eksklusi jika tahun publikasi atau tahun terbit jurnal telah melebihi 10 tahun, kecuali apabila jurnal merupakan jurnal yang memuat informasi mendasar yang masih relevan. Terdapat 125 artikel atau jurnal ilmiah yang sesuai dengan topik yang dibahas, namun hanya 81 jurnal atau publikasi yang memenuhi kriteria inklusi dan eksklusi yang telah ditetapkan oleh penulis.

\section{HASIL DAN PEMBAHASAN}

\section{Patofisiologi-Patogenesis Katarak dan Katarak Diabetik}

Saat ini masih terdapat beberapa teori yang menyebabkan terjadinya katarak yaitu teori hidrasi dan sklerosis. ${ }^{19}$ Teori hidrasi terjadi kegagalan mekanisme pompa aktif pada epitel lensa yang berada di subkapsular anterior, sehingga air tidak dapat dikeluarkan dari lensa. Air yang banyak ini akan menimbulkan bertambahnya tekanan osmotik yang menyebabkan kekeruhan lensa. Teori sklerosis lebih banyak terjadi pada lensa manula dimana serabut kolagen terus bertambah sehingga terjadi pemadatan serabut kolagen ditengah. Makin lama serabut tersebut semakin bertambah 
banyak sehingga terjadilah sklerosis nukleus lensa. ${ }^{20}$

Hal yang saat ini menjadi titik pembahasan adalah jalur metabolisme pada katarak diabetik yang membahas tentang teori klasik tentang teori osmotik katarak. Lensa mata adalah organ avaskuler yang terletak di bilik mata belakang dan dibagian depan dikelilingi oleh cairan aqueous. Cairan aqueous ini merupakan sumber nutrisi bagi lensa dan juga berfungsi sebagai penampung hasil metabolit yang diekskresi oleh jaringan sekitarnya. Berbeda dengan pada sel yang lain, glukosa dapat masuk ke dalam lensa mata dengan bebas, melalui proses difusi tanpa bantuan insulin. Di dalam lensa pemecahan glukosa sebagian besar 78\% melalui jalur glikolisis anaerobik, 14\% melalui jalur pentosa fosfat dan sekitar 5\% melalui jalur poliol. Pada kondisi hiperglikemia, jalur glikolisis anaerobik cepat jenuh, dan glukosa akan memilih jalur poliol. ${ }^{21,22,23}$

Pada jalur poliol glukosa dirubah menjadi sorbitol yaitu bentuk alkoholnya. Disini seharusnya kemudian sorbitol dipecah menjadi fruktosa oleh enzim poliol dehidrogenase, namun pada diabetes melitus kadar enzim poliol dehidrogenase rendah sehingga sorbitol menumpuk di dalam lensa mata. Hal ini menyebabkan terjadinya kondisi hipertonik yang akan menarik masuk cairan aqueous ke dalam lensa mata, merusak arsitektur lensa dan terjadilah kekeruhan lensa (teori osmotik katarak pada diabetes melitus). ${ }^{24,25}$

Lensa bagian depan selalu dibasahi oleh cairan aqueous yang banyak mengandung hidrogen peroksida $\left(\mathrm{H}_{2} \mathrm{O}_{2}\right)$. Selain itu $\mathrm{H}_{2} \mathrm{O}_{2}$ juga diproduksi oleh sel epitel lensa mata dan serat fiber lensa. Hidrogen peroksida ini dapat menembus membran sel. ${ }^{\mathrm{x}} \mathrm{H}_{2} \mathrm{O}_{2}$ bukan radikal bebas, tetapi merupakan oksidan kuat karena dapat mengoksidasi berbagai senyawa yang terdapat di dalam sel misalnya glutation. Selain merupakan oksidan kuat, $\mathrm{H}_{2} \mathrm{O}_{2}$ dapat menghasilkan radikal hidroksil bila bereaksi dengan logam transisi, $\mathrm{Fe}^{++}$dan
$\mathrm{Cu}^{+}$melalui reaksi Fenton. $\mathrm{H}_{2} \mathrm{O}_{2}$ melimpah inilah yang merupakan sumber awal produksi radikal bebas pada lensa mata diabetes, $\mathrm{H}_{2} \mathrm{O}_{2}$ juga sekaligus dapat diproduksi oleh rangkaian reaksi radikal bebas pada lensa mata itu sendiri. ${ }^{26,27,28}$

Mekanisme toksisitas glukosa pada diabetes melitus yang menyebabkan terjadinya katarak diabetik pada dasarnya dapat melalui tiga jalur, Pertama, akibat peningkatan aktivitas enzim aldose reduktase yang menyebabkan terbentuknya gula alkohol, sorbitol dan galaktitol pada kristalin lensa. Kedua, melalui proses glikasi non-enzimatik dimana glukosa yang mempunyai senyawa reaktif karbonil $(\mathrm{C}=\mathrm{O})$ akan berikatan dengan gugus amino protein kristalin lensa $\left(-\mathrm{NH}_{2}\right)$. Reaksi ini akan menyebabkan penurunan tingkat kelarutan protein. Ketiga, pada kadar glukosa darah yang tinggi akan terjadi proses gluko-oksidasi yang menyebabkan terjadinya kondisi stres oksidatif. ${ }^{29}$

Glukosa dapat menjadi toksik diakibatkan oleh karena memiliki gugus reaktif karbonil $(\mathrm{C}=\mathrm{O})$ yang secara kimiawi dapat sebagai aldehid yaitu suatu bahan reaktif yang dapat berikatan dengan gugus amino protein (-NH2), fosfolipid dan DNA. Umumnya bentuk glukosa dalam larutan berupa non-aldehid, namun molekul glukosa yang berada dalam bentuk lurus (terbuka) merupakan aldehid. Dalam bentuk glukosa (non-aldehid) maka reaksi dengan protein, serta DNA berlangsung lambat, reaksi memodifikasi molekul molekul tersebut disebut glikasi non-enzimatik. Reaksi berjalan lambat dan reversibel pada suhu $37^{\circ} \mathrm{C}$, dan hanya bermakna pada protein dengan turnover lambat seperti kristalin dalam lensa maupun kolagen pada jaringan ikat. Namun pada kondisi diabetes, kerena konsentrasi glukosa yang tinggi, intensitas reaksi glikasi non-enzimatik yang sangat meningkat dapat dideteksi pada berbagai protein dan makromolekul yang lain. $^{21,22,23,24}$

Pada diabetes melitus reaksi glikasi non-enzimatik dapat terjadi pada kapsul, 
sel epitel maupun serat fiber lensa. ${ }^{22}$ Reaksi glikasi non-enzimatik adalah reaksi yang terjadi antara gula (aldehid) dengan asam amino (protein). Reaksi ini berjalan dalam dua fase yaitu, fase reversibel dan fase irreversibel. Fase reversibel ditandai dengan terbentuknya protein basa Schiff dan produk Amadori, dan fase irreversibel ditandai dengan terbentuknya advanced glycations end product (AGEs). Pada kondisi hiperglikemia, glukosa didalam tubuh baik ekstra maupun intra seluler mengalami dua proses non-enzimatik penting yang berhubungan dengan terbentuknya AGEs. ${ }^{30}$

Pertama, pembentukan glikasi protein yang terjadi bila grup aldehid dari glukosa bereaksi dengan asam amino bebas dari protein. Basa shifft kemudian akan mengalami intra molecular arrangement (Amadori arrangement) dan menjadiprotein glikasi,: fruktosil protein atau 3-deoksiglukosonil protein. Kedua, glukosa dapat mengalami oksidasi dan membentuk senyawa dikarbonil, yaitu $\alpha$ glucosone dan senyawa oksigen reaktif superoksida $\left(\mathrm{O}_{2}{ }^{-}\right)$. Selanjutnya senyawa oksigen reaktif superoksida $\left(\mathrm{O}_{2}^{-}\right)$dapat menghasilkan hidrogen peroksida $\left(\mathrm{H}_{2} \mathrm{O}_{2}\right)$ dan radikal hidroksil $(\mathrm{OH})$. Reaksi ini dikatalisa oleh superoksida dismutase (SOD). $\mathrm{H}_{2} \mathrm{O}_{2}$ kemudian bereaksi dengan molekul superoksida yang lain dan membentuk radikal hidroksil. Reaksi ini disebut reaksi Haber-Weiss, dimana reaksi ini menghasilkan ion $\mathrm{Fe}^{3+}$ atau $\mathrm{Cu}^{2+}$. Jadi oksidasi non-enzimatik dari glukosa dapat menghasilkan senyawa dikarbonil yang reaktif dan senyawa oksigen reaktif seperti radikal super oksid $\left(\mathrm{O}_{2}^{-}\right)$, hidrogen peroksida $\left(\mathrm{H}_{2} \mathrm{O}_{2}\right)$, dan radikal hidroksil $(\mathrm{OH})$. Reaksi kimia antara protein dan senyawa dikarbonil seperti glioksal dan 3deoksiglukoson atau oksidasi dari glikasi protein menghasilkan AGE. Jadi AGEs adalah suatu molekul heterogen yang merupakan penggabungan dari protein dan produk oksidatif dari glukosa. ${ }^{30}$

Reaksi glikasi non-enzimatik protein kristalin akan menimbulkan cross-link antar dan intra molekul protein sehingga terjadi penambahan high molecular weight protein yang akan diikuti oleh terjadinya agregasi protein sehingga merusak kejernihan lensa dan terjadi katarak. Kadar glukosa darah yang tinggi akan memicu terjadinya reaksi glikasi non-enzimatik dimana gula (aldehid) akan bereaksi dengan asam amino (protein) yang memicu penurunan aktivitas pada enzim superoksida dismutase dan katalase. ${ }^{9}$ Radikal superoksida akan bereaksi dengan membran sel membentuk lipid perosida (MDA), yang mencerminkan kerusakan sel (nekrotik). Dengan terdapatnya enzim superoksida dismutase maka radikal superoksida akan dirubah menjadi hidrogen peroksida. Disisi lain hidrogen peroksida yang bergabung dengan radikal superoksida dengan adanya besi, melalui reaksi Habber-Weiss. Fenton dapat menimbulkan radikal hidroksil yang sangat toksik terhadap DNA, sehingga akan terjadi cacat pada DNA, dan selanjutnya dapat menimbulkan kerusakan pada lensa. Kerusakan pada lensa mata diawali oleh kerusakan pada sel epitel lensa yang merupakan pusat metabolisme lensa serta memegang peranan penting dalam mempertahankan kejernihan lensa mata. Kematian sel epitel lensa mata diikuti kerusakan pada serat fiber lensa yang apabila berlanjut akan merusak arsitektur dan homogenitas lensa sehingga terjadi katarak. ${ }^{21}$

Mekanisme pertahanan terhadap senyawa oksigen reaktif dilakukan oleh sistem enzim dan sistem non-enzim. Pada lensa mata mekanisme pertahanan enzimatis terhadap senyawa oksigen reaktif bergantung pada tiga sistem, yaitu glutation siklus redoks, enzim superoxida dismutase, dan katalase. Sistem glutation (glutation siklus redoks) merupakan mekanisme pertahanan yang utama terhadap senyawa oksigen reaktif. $21,22,30$, 31

Pada diabetes melitus terjadi penurunan dihidro nikotinamida adenin dinukleotida fosfat (NADPH) karena, alur pentosa 
posfat dimulai dari glukosa-6-P, pada diabetes melitus, hormon insulin menurun, sehingga aktivitas glukokinase menurun, aktivitas alur pentosa fosfat menurun yang menyebabkan NADPH menurun. Sementara, pada hiperglikemia terjadi oksidasi non enzimatik menghasilkan reactive oxygen species (ROS) dan pembentukan senyawa dikarbonil. Alur poliol meningkat, karena pada diabetes melitus, glukokinase menurun, glikolisis menurun, alur pentosa menurun, jadi tinggal alur poliol. ${ }^{31}$

Glutation adalah suatu senyawa tripeptida yang mengandung gugusan sulfhidril (-SH). Pada lensa mata glutation terdapat dalam jumlah yang berlimpah, konsentrasi glutation tertinggi didapatkan pada epitel lensa. Sebagian besar glutation bebas terdapat dalam bentuk glutation tereduksi (GSH) dan hanya sekitar 2\% $5 \%$ terdapat dalam bentuk glutation teroksidasi (GSSG). Molekul GSH disintesa dalam dua tahap yaitu, Pertama, enzim $\gamma-$ glutamil sistein sintetase akan mengkatalisa pembentukan dipeptida produk yang dihasilkan pada reaksi tersebut oleh glutation sintetase akan dirubah menjadi GSH, GSH merupakan glutation yang aktif mengikat $\mathrm{H}_{2} \mathrm{O}_{2}$ yang akan dirubah menjadi $\mathrm{H}_{2} \mathrm{O}$ dan GSSG dengan bantuan enzim glutation peroksidase. Kemudian GSSG akan dirubah kembali menjadi GSH oleh enzim glutation reduktase dan pada reaksi ini diperlukan NADPH. Siklus ini (siklus redoks glutation) merupakan mekanisme pertahanan yang utama terhadap senyawa oksigen reaktif pada lensa mata. Akibat rendahnya NADPH pada diabetes melitus ini maka diduga aktivitas siklus redoks glutation juga akan menurun sehingga mengakibatkan terjadinya peningkatan $\mathrm{H}_{2} \mathrm{O}_{2}$, peningkatan radikal hidroksil dan peningkatan lipid peroksida dan malonialdehid (MDA) yang akan merusak artisektur lensa mata sehingga terjadi

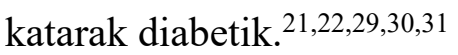

\section{Sel Punca dan Potensi Terapi Berbasis Sel}

Sel punca merupakan sel yang belum berdiferensiasi dan memiliki potensi tinggi untuk menjadi sel yang lain. Sel punca memiliki karakteristik antara lain, masingmasing sel dapat membentuk koloni; semua sel berasal dari satu sel dan mempunyai sifat genetik yang sama (clonogenic), untuk membelah tak terbatas (self renewing), mampu berubah (differentiation) menjadi berbagai jenis sel (plasticity). Sel punca yang berbeda dapat dikelompokkan secara anatomi, fungsinya, petanda pada permukaan sel (cell surface markers) yang berbeda, faktor transkripsi serta protein yang diekspresikan. ${ }^{32}$

Terdapat berbagai jenis sel punca antara lain, Sel punca embrionik berasal dari inner cell mass dari blastokista, yang dapat berproliferasi bebas dan pluripoten. Serta, sel punca dari darah umbilical cord blood (tali pusat) dan jaringan plasenta. Selain itu ada sel punca dewasa, yang multipoten. Sumber terapi sel punca autologus merupakan sumber ideal karena dapat menghindari berbagai kemungkinan rejeksi, walaupun terapi sel punca alogenik mempunyai kemungkinan besar sebagai sumber sel punca. Sel punca yang banyak digunakan saat ini adalah sel mononuklear sumsum tulang, sel punca darah tepi yang dimobilisasi, sel CD34 atau CD133 yang dimurnikan, sel punca mesenkimal autologus, sel punca mesenkimal plasenta dan sumsum tulang alogenik. ${ }^{32,33,34}$

\section{TEMPE (RHYZOPUS.SP)}

\section{Fitur Klinis Tempe sebagai Sumber Fitoestrogen}

Tempe (Rhyzopus.sp) adalah salah satu produk fermentasi yang umumnya berbahan baku kedelai yang difermentasi dan mempunyai nilai gizi yang baik. Fermentasi pada pembuatan tempe terjadi karena aktivitas kapang Rhizopus oligosporus. Fermentasi pada tempe dapat 
menghilangkan bau langu dari kedelai yang disebabkan oleh aktivitas dari enzim lipoksigenase. Fermentasi kedelai menjadi tempe akan meningkatkan kandungan fosfor. Hal ini disebabkan oleh hasil kerja enzim fitase yang dihasilkan kapang Rhizopus oligosporus yang mampu menghidrolisis asam fitat menjadi inositol dan fosfat yang bebas. ${ }^{35,36}$

Tempe merupakan sumber protein yang baik. Setiap $100 \mathrm{~g}$ tempe mengandung 18$20 \mathrm{~g}$ zat protein dan $4 \mathrm{~g}$ zat lemak. Tempe juga memiliki berbagai sifat unggul seperti mengandung lemak jenuh rendah, kadar vitamin B12 tinggi, mengandung antibiotik, dan berpengaruh baik pada pertumbuhan badan. Selain itu tempe memiliki indeks glikemik yang rendah. Sementara itu, dari manfaat kesehatan tempe berpotensi sebagai makanan yang mengandung bahan yang mirip dengan hormon estrogen yang berfungsi sebagai repair organ-organ dan bagian tubuh yang rusak seperti lensa akibat penyakit katarak. $37,38,39,40$

\section{Potensi Fitoestrogen Tempe sebagai Aktivator Pengaktifan Sel Punca pada Perbaikan Fungsi Lensa Penyakit Katarak}

Tempe merupakan hasil fermentasi dari kacang kedelai yang mengandung isoflavonoid. Isoflavonoid dapat berfungsi sebagai fitoestrogen di dalam tubuh manusia dan memiliki fungsi yang sama dengan 17 $\beta$-estradiol. Selain itu, isoflavonoid bertindak pada reseptor yang sama. Mekanisme normal dalam tubuh manusia, $17 \beta$-estradiol akan mengaktivasi sinyal parakrin Akt dan SDF-1 yang akan mempercepat laju dan meningkatkan efektivitas MSC/iPSC dalam memperbaiki kapsula lentis yang rusak dan pembentukan serat-serat lamelar subepitel. ${ }^{41}$

Sesuai dengan patogenesis dari terjadinya penyakit katarak, terjadi kegagalan mekanisme pompa aktif pada epitel lensa yang berada di subkapsular anterior, sehingga air tidak dapat dikeluarkan dari lensa. Air yang banyak ini akan menimbulkan bertambahnya tekanan osmotik yang menyebabkan kekeruhan lensa. Selain itu faktor sklerosis akan menyebabkan terjadinya penambahan serabut kolagen yang akan menyebabkan terjadinya pemadatan serabut kolagen pada lensa dan retina mata. Selanjutnya, faktor trankripsi OCT-4, SOX-2, dan KLF-4 (faktor Yamanaka) yang berperan dalam faktor pemrograman ulang akan menginduksi Fbx15, selanjutnya Fbx15 akan memicu $\alpha \mathrm{A}$-crystallin dan epithelial progenitors cell (EPC) sehingga akan berikatan dengan reseptor estrogen receptors $\alpha(\mathrm{ER} \alpha)$ dan estrogen receptors $\beta$ (ER $\beta$ ) sehingga memicu $17 \beta$-estradiol untuk mengaktivasi sinyal parakrin Akt dan SDF-1 dan memobilisasi sel punca yang berasal sum-sum tulang/ sel epitel untuk berpindah ke serat-serat lamelar subepitelial yang rusak. ${ }^{42}$

Konsentrasi $17 \beta$-estradiol ditentukan banyaknya hormon ini dihasilkan oleh tubuh. Seiring dengan bertambahnya usia hormon ini akan menurun, sehingga menurun pula mekanisme pertahanan tubuh untuk mengaktifkan sel punca. Belum lagi dengan jumlah $17 \beta$-estradiol tidak sepenuhnya mampu membantu perubahan kapsula lentis dan memperbaiki serat lamelar yang rusak. Sehingga, dengan penambahan konsumsi tempe yang mengandung fitoestrogen mampu membantu perbaikan lensa. Selain itu tempe juga mampu mencegah dengan fungsinya sebagai antioksidan. ${ }^{43}$

\section{Potensi Fitoestrogen Tempe sebagai Isoflavonoid pada Perbaikan Lensa Penyakit Katarak}

Tempe merupakan hasil fermentasi dari kacang kedelai yang memiliki kandungan isoflavonoid yang tinggi. Tempe dapat terjangkau oleh seluruh kalangan. Selain itu tempe mudah untuk didapatkan. Namun sayangnya tempe tidak terlalu mendapatkan perhatian khusus. Padahal di 
satu sisi tempe mampu dijadikan makanan untuk membantu penyembuhan penyakit katarak. Dalam $250 \mathrm{mg}$ tempe terdapat kandungan isoflavonoid sebanyak $20 \mathrm{mg}$. Sehingga dengan pengkonsumsian tempe sebanyak $750 \mathrm{mg}$ sudah dihasilkan isoflavonoid sebanyak $70 \mathrm{mg}$. di dalam tubuh yang mampu menghasilkan efek yang sama dengan $17 \beta$-estradiol. ${ }^{42,43}$ Mengnsumsi tempe sebanyak $750 \mathrm{mg}$ sudah dihasilkan isoflavonoid sebanyak 70 mg di dalam tubuh yang mampu menghasilkan efek yang sama dengan $17 \beta$ estradiol. ${ }^{42,43}$

\section{Potensi Fitoestrogen Tempe sebagai Sumber Protein Morfogenetik pada Perbaikan Lensa Penyakit Katarak}

Tempe sebagai produk bioteknologi modern dapat membantu kelangsungan hidup sel melalui pengaktifan bone morphogenetic protein-7 (BMP-7) dari epithelial progenitors cell atau mesenchymal stem cell sum-sum tulang belakang pada dalam menjaga kelangsungan hidup sel dengan mencegah faktor kematian sel epitel lensa yaitu faktor transforming growth factor beta-2 (TGFb2). ${ }^{44,45,46}$

Selain itu, BMP-7 mencegah kerusakan dari epidermal growth factor (EMT) sebagai faktor pertumbuhan sekaligus sebagau perbaikan lamelar subepitel pada lensa. TGFb berikatan dengan reseptor serin-treonin kinase tipe II yang berbeda, kemudian membentuk kompleks dengan reseptor serin-treonin kinase tipe I. Kompleks reseptor yang diaktifkan ini akan melanjutkan pensinyalan asam amino kedalam sitoplasma dengan memfosforilasi small mothers against decapentaplegi (Smad) 2/3 dalam pensinyalan $\mathrm{TGFb}$ dan Smad1 atau 5/8 dalam pensinyalan BMP. Smads yang terfosforilasi hetero-oligomerisasi dengan Smad4, akan diaktivasi $\mathrm{TGFb}$ dan BMP signaling, yang mentranslokasi ke nukleus untuk mengatur transkripsi dari gen target pada lensa. ${ }^{47,48}$

\section{BAWANG PUTIH (ALLIUM SATIVUM) \\ Fitur Klinis Bawang Putih sebagai Sumber Metanolik}

Bawang putih (Allium sativum) adalah herba semusim berumpun yang mempunyai ketinggian sekitar $60 \mathrm{~cm}$. Tanaman ini banyak ditanam di ladang-ladang di daerah pegunungan yang cukup mendapat sinar. ${ }^{49}$

Allisin dan komponen sulfur lain yang terkandung di dalam bawang putih dipercaya sebagai bahan aktif yang berperan dalam efek antibakteri bawang putih. Zat aktif inilah yang dilaporkan memiliki aktivitas antibakteri dengan spektrum yang luas. Allisin (diallyl thiosulfinate) merupakan salah satu komponen biologis yang paling aktif yang terkandung dalam bawang putih. Komponen ini, bersamaan dengan komponen sulfur lain yang terkandung dalam bawang putih berperan pula memberikan bau yang khas pada bawang putih. Selain itu, bawang putih memiliki substansi metanolik yang berperan sebagai antioksidan dan berperan dalam efek terapeutik. Ekstrak umbi pada bawang putih merupakan bagian pada bawang putih yang berpotensi dalam mengobati efek opasitas lensa pada katarak diabetik. ${ }^{50,51}$

\section{Potensi Metanolik Ekstrak Bawang Putih sebagai Terapi Preventif Berbasis Etnobotani Pada Katarak Diabetik}

Lensa atau biasa disebut kristalin adalah bagian mata yang terletak di belakang pupil mata yang berfungsi untuk memfokuskan cahaya ke retina. Lensa didukung oleh otot yang disebut muskulus siliaris (otot daging yang melingkar). Apabila otot ini berkontraksi akan terjadi perubahan ukuran lensa. Kemampuan lensa mata ini dinamakan daya akomodasi. ${ }^{52}$ Ruangan di antara lensa dan kornea berisi cairan encer yang disebut 
aqueous humor. Di bagian bola mata berisi cairan kental dan transparan yang menyebabkan bola mata menjadi kukuh. Cairan ini disebut vitreous humor.

Dalam keadaan katarak diabetik, terjadi fenomena perubahan karakteristik permeabilitas membran dan kebocoran protein struktural atau kapsul lensa akibat produksi reactive oxygen species (ROS) signifikan akibat hiperglikemia yang dapat mencetuskan terjadinya stres oksidatif dengan proses auto-oksidasi glukosa sehingga membentuk ROS selama proses glikasi. Stres oksidatif terjadi akibat ketidakseimbangan antara pembentukan radikal bebas dengan kemampuan antioksidan alami dari tubuh. ${ }^{53}$

Proses pembentukan karaktogenesis sebagai perjalanan panjang perubahan lensa menjadi opasitas terjadi akibat faktor utama kadar glukosa darah yang tinggi sehingga akan menyebabkan terjadinya perubahan rasio oksidan pada antioksidan sehingga akan menyebabkan terjadinya dishomeostasis kation, sehingga akan mencetuskan katalisis reaksi logam transisi sebagai produk akhir glikasi dan mailard. Katalisis reaksi ini akan meningkatkan faktor transkripsi induced nitric oxide synthase (iNOS) dan fluks poliol. ${ }^{54,55}$

Dalam penatalaksanaan katarak, Bawang putih merupakan bahan rempahrempah famili Liliaceae, genus Alliaceae yang secara luas digunakan sebagai bumbu masak, pengobatan penyakit, antioksidan dan antihiperglikemia. Berdasarkan laporan penelitian Zhao dan Shichi ${ }^{56}$, Bawang putih memiliki molekul bioaktif berupa diallyl disulfida (DADS) dalam dosis $200 \mathrm{mg} / \mathrm{kg}$ dan kadar metanolik yang dapat mencegah laju hidrasi dan penurunan konsentrasi fruktosa dan fosfor pada lensa yang diinkubasi medium galaktosa dan xilosa sebagai bahan protektif aksi melawan katarak. Metanol pada ekstrak bawang putih dapat meningkatkan status antioksidan, mengurangi kadar iNOS dan mengurangi senyawa oksidasi berupa kation sebagai pencetus terjadinya opasitas lensa. ${ }^{57}$

\section{Potensi Metanolik Ekstrak Bawang Putih sebagai Efek Hipoglikemik yang Efektif}

Metanolik merupakan senyawa bioaktif pada bawang putih yang berpotensi mencegah laju hidrasi dan penurunan konsentrasi fruktosa dan fosfor pada lensa yang diinkubasi medium galaktosa dan xilosa sebagai bahan protektif aksi melawan katarak. Selain itu, metanolik bawang putih berkhasiat dalam memulung ion logam yang dikatalisasi $\mathrm{H}_{2} \mathrm{O}_{2}$. Hal tersebut menandakan bahwa metanolik bawang berkhasiat dalam melawan ion logam yang bersifat oksidatif dan secara signifikan dapat menurunkan kadar glukosa plasma. Penelitian secara in-vitro terhadap tikus membuktikan bahwa pengaruh metanolik pada ekstrak bawang putih telah diamati selama 8 minggu terhadap tikus diabetes dan tikus kontrol. Pada tikus diabetes yang diberikan metanolik ekstrak bawang putih terjadi penurunan kadar glukosa plasma sebanyak 3 kali lipat dibandingkan tikus kontrol. Hal ini membuktikan bahwa metanolik ekstrak bawang putih terbukti memiliki efek hipoglikemik yang efektif. ${ }^{55,58,59,60}$ 
Grafik 1. Efek Metanolik Ekstrak Bawang Putih pada Level Glukosa Plasma. ${ }^{60}$

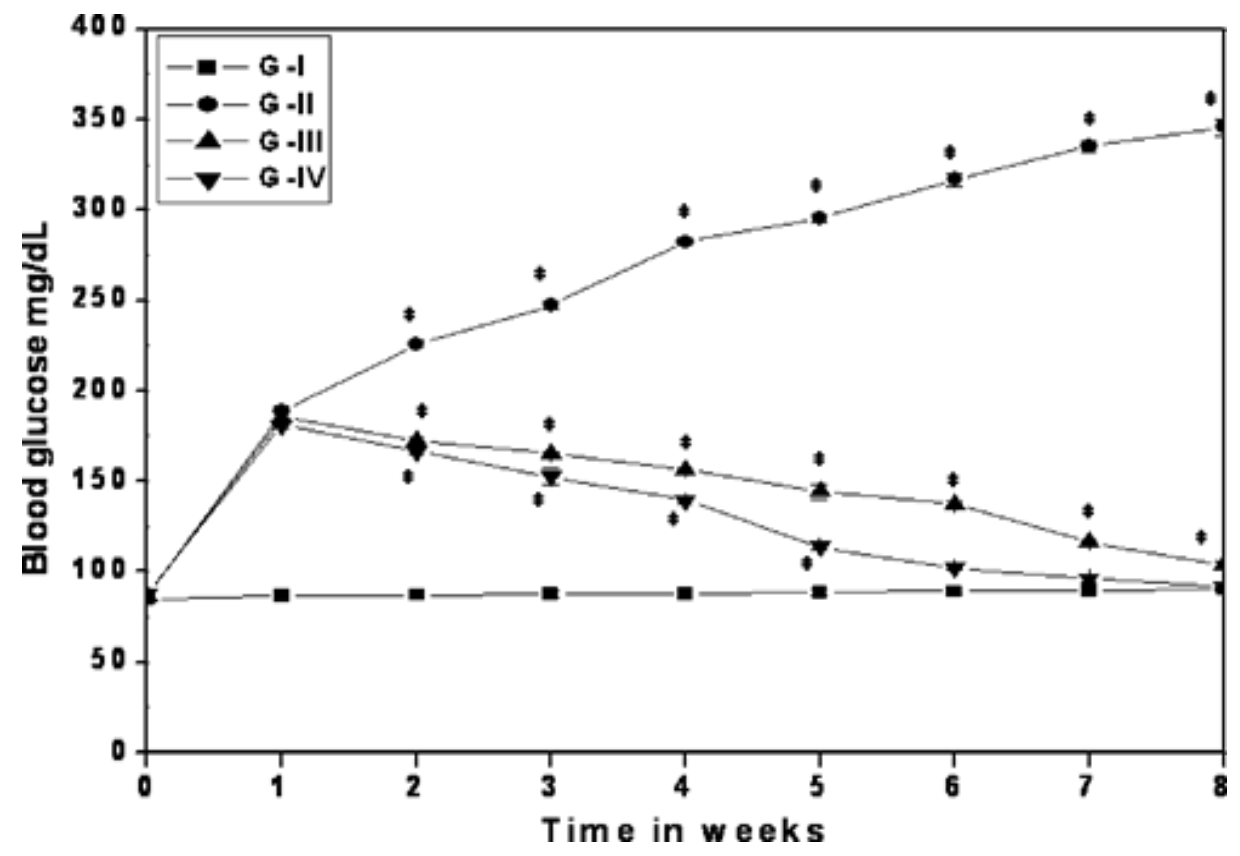

\section{Potensi Metanolik Ekstrak Bawang Putih sebagai Katalisator Faktor Stres Oksidatif pada Lensa}

Pemberian metanolik ekstrak bawang putih telah terbukti dalam menurunkan aldose reduktase (AR) dimana aktivitas AR yang menyebabkan terbentuknya gula alkohol, sorbitol dan galaktitol pada kristalin lensa. Selain itu aktivitas dari sorbitol dehidrogenase (SDH), dapat ditekan oleh pemberian metanolik ekstrak bawang putih. Pada kondisi hiperglikemia, jalur glikolisis anaerobik cepat jenuh, dan glukosa akan memilih jalur poliol. Pada jalur poliol glukosa SDH dirubah menjadi sorbitol, dimana sorbitol dipecah menjadi fruktosa oleh enzim poliol dehidrogenase, namun pada kondisi hiperglikemia kadar enzim poliol dehidrogenase rendah sehingga sorbitol menumpuk di dalam lensa mata. Keadaan kondisi hipertonik akan menarik masuk cairan aqueous ke dalam lensa mata, merusak arsitektur lensa dan terjadi kekeruhan lensa. ${ }^{61,62,63}$

Penelitian yang dilakukan oleh Hayman et $a l^{64}$, penelitian secara in-vitro menunjukkan bahwa pemberian metanolik ekstrak bawang putih menurunkan kadar AR dan SDH sebanyak 1,3 kali lipat. Penelitian ini diperkuat oleh penelitian Gerlach et $a l^{65}$ yang menunjukkan bahwa pemberian metanolik ekstrak pada tikus dengan berat badan $200 \mathrm{mg}$, menurunkan secara signifikan kadar elevasi ion $\mathrm{Ca}^{2+}$, $\mathrm{Cu}^{2+}, \mathrm{Na}^{+}$, dan $\mathrm{Mg}^{2+}$ sebagai penginduksi kekeruhan lensa. Efek lainnya, pada penelitian ini dapat menurnkan agregasi protein dan permeabilitas lensa yang diinduksi ion logam oksidatif sebanyak 2-5 kali lipat bahkan efeknya sampai dapat menunjukkan tingkat normalisasi ion logam oksidatif akibat stres dan hiperglikemia. ${ }^{66,67,68,69}$ 


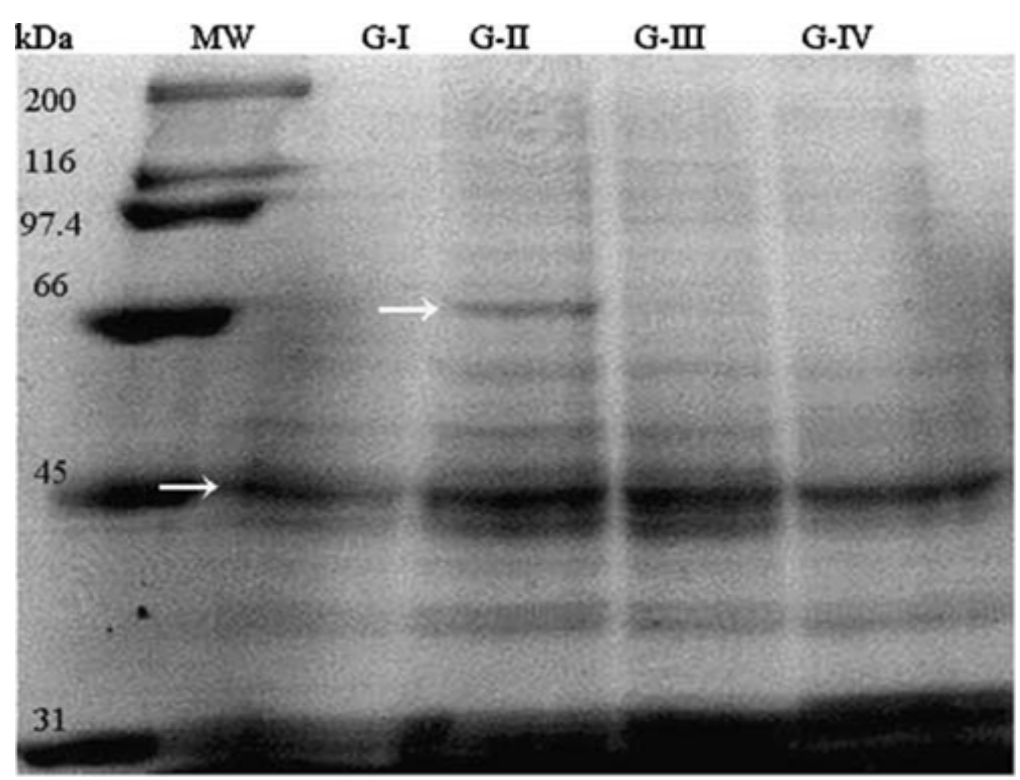

Gambar 1. Pengaruh Metanolik Ekstrak Bawang Putih sebagai Katalisator Stres Oksidatif. ${ }^{62,70}$

Potensi Metanolik Ekstrak Bawang Putih sebagai Fungsi Perbaikan Protein Lensa

Pada katarak, terjadi agregasi dan insolubilisasi protein akibat pengaruh kebocoran membran pada lensa. Pemberian metanolik ekstrak bawang putih dapat menurunkan kadar fraksi protein baik yang terlarut maupun protein total sebagai faktor pencetus opasitas lensa akibat insolubilisasi protein. ${ }^{71,72,73}$
Penelitian oleh Chavveri et al 62 menujukkan bahwa pada tikus yang diberikan pelindung lensa dengan dosis 0,5 $\mathrm{g} / \mathrm{KgBB}$ setelah dilakukan elektroforesis pada kadar sodium dodesil sulfat (SDS) menunjukkan penurunan kadar protein ${ }^{74,75}$, penurunan kadar floresensi dan berat molekular asam amino triptofan menjadi $66,2 \mathrm{kDa}^{76,77}$ Hal ini menunjukkan efek penurunan kadar fraksi protein pada lensa.

Grafik 2. Pengaruh Metanolik Ekstrak Bawang Putih pada Perbaikan Protein Lensa. ${ }^{62,70}$

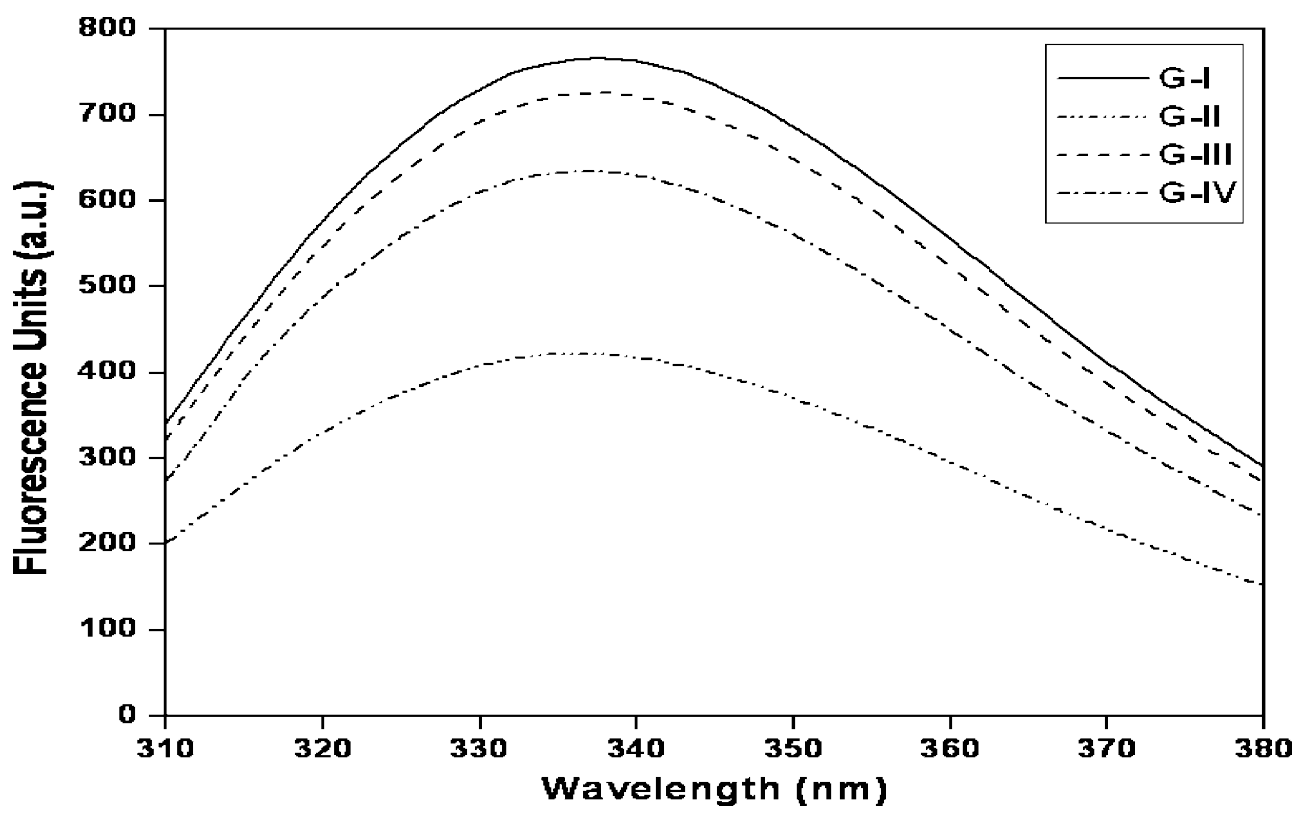




\section{Potensi Metanolik Ekstrak Bawang Putih sebagai Aplikasi Terapi Etnobotani yang Efektif}

Katarak dewasa ini, menjadi momok besar dan buah bibir permasalahan kesehatan yang menyebabakan besarnya beban sosial ekonomi bagi populasi di dunia. Terbarukan dewasa ini, belum ada agen terapeutik yang dapat mencegah dan menghambat kekeruhan lensa. Memanfaatkan kekayaan alam sesuai etika dan regulasinya telah menjadi prinsip pentalaksanaan bersifat alamiah untuk mengobati penyakit katarak salah satunya dengan memanfaatkan tumbuhan bawang putih sebagai intervensi jalur metabolisme. Bawang putih merupakan tanaman yang banyak dibudidayakan dan digunakan karena signifikansi farmakologis yang efektif dan kandungan alami pada bawang yang berkhasiat dalam mencegah penyakit katarak diabetik yaitu, metanolik. Metanolik didapatkan dari umbi bawang putih yang diekstrak. ${ }^{78}$

Metanolik pada bawang putih mempunyai efektivitas dalam memulung ion transisi $\mathrm{H}_{2} \mathrm{O}_{2}$, sebagai antioksidan yang dapat encegah modifikasi protein yang dimediasi melalui reaksi katalisis logam pada lensa katarak. Faktor lain seperti stres oksidatif akan meningkatkan oksi-radikal melalui auto-oksidasi glukosa, akumulasi gula alkohol yang berakibat pada peningkatan enzim poliol dan karakteristik perubahan permeabilitas membran. Permeabilitas membran dapat berubah ketika terjadi peningkatan $\mathrm{Ca}^{2+}$ intraseluler, $\mathrm{Cu}^{2+}, \mathrm{Na}^{+}$, dan $\mathrm{Mg}^{2+}$ dan menurunkan level $\mathrm{K}^{+}$yang dapat mencetuskan aktifnya kadar protease, insolubilisasi protein dan agregasi protein yang dapat meningkatkan penyebaran cahaya pada lensa yang berujung pada opasitas lensa. ${ }^{79,80}$

Pada keadaan hiperglikemia, permeabilitas membran yang teraktivasi karena penyebab ketidakseimbangan elektrolit dapat menyebabkan regulasi transkrip mRNA iNOS tercetus dan dapat menginduksi pensinyalan stres oksidatif melalui senyawa nitrat oksida. Selain aktivitas nitrat oksida tersebut, kadar thiobarbituric acid reactive substances (TBARs) dan karbonil dapat mencetuskan stres oksidatif. ${ }^{71,74,75,76}$ Tetapi, dengan pemberian metanolik dari ekstrak bawang putih dapat mengembalikan jalur normal dari metabolisme glukosa, menunjukkan tingkat potensi hiopoglikemik.

Peran metanolik pada ekstrak bawang putih dapat menekan dari laju enzim poliol yang terlibat dalam pemeliharaan tekanan osmotik, kesetimbangan oksidatif dan integritas permeabilitas membran lensa. Selain itu efek yang dihasilkan dari metanolik ekstrak bawang putih yaitu pemulihan elektrolit, konten GSH antioksidan cadangan, mengatasi terjadinya agregasi protein, downregulasi transkrip mRNA iNOS, konten TBARS dan karbonil. Selain daripada substansi metanolik pada ekstrak umbi bawang putih seperti allisin dan ajoene dapat membantu tindakan perbaikan pada pernyataan sebelumnya pada gangguan pengelihatan seperti katarak dan glaukoma. ${ }^{79,80,81}$

Kekeruhan lentikular terkait stres oksidatif akibat hiperglikemia pada diabetes melitus merupakan problematika paling krusial yang manifestasi jangka panjangnya dapat menyebabkan kebutaan. Perkembangan intervensi terapeutik berbasis tumbuhan obat seperti bawang putih merupakan solusi aman dan jangka panjang yang memiliki khasiat untuk meningkatkan transparansi lensa. ${ }^{81}$

Tabel.4 Efek Pemberian Metanolik dalam Meningkatkan Transparansi Lensa. ${ }^{13}$

\section{KESIMPULAN DAN SARAN}

\section{Kesimpulan}

Pengembangan makanan dan tumbuhan berbasis bahan lokal Indonesia saat ini telah dikembangkan sebagai terapi perbaikan fungsi lensa dan pencegahan pada stres oksidatif dan hiperglikemia 
pada katarak diabetik yaitu, tempe dan bawang putih.

Tempe memiliki kandungan nutrisi yang tinggi yaitu terdiri atas kalsium, vitamin $\mathrm{B}$, zat besi, antioksidan dan isoflavonoid. Isoflavonoid sebagai sumber fitoestrogen memiliki peran yang sama persis dengan 17 $\beta$-estradiol. Sehingga mampu bekerja di reseptor yang sama dengan 17 $\beta$-estradiol dan memunculkan efek yang sama. Fitoestrogen akan berperan mengaktivasi sinyal parakrin Akt dan SDF-1. Fitoestrogen akan mempercepat laju sel dan berikatan dengan reseptor yang tepat, sehingga mampu meningkatkan efektivias kerja sel punca untuk memperbaiki sel pada lensa katarak.

Bawang putih sebagai tumbuhan yang memiliki potensi substansi bioaktif metanolik memiliki efek antioksidan yang tinggi dalam memulung ion-ion oksidatif dan kadar senyawa $\mathrm{H}_{2} \mathrm{O}_{2}$. Selain itu potensi bawang putih sebagai antioksidan dapat mencegah stres oksidatif, kebocoran permeabilitas membran dan kebocoran protein struktural atau kapsul lensa akibat produksi ROS signifikan akibat hiperglikemia yang dapat mencetuskan terjadinya stres oksidatif dengan proses auto-oksidasi glukosa sehingga membentuk ROS selama proses glikasi. Efek pada bawang putih telah teruji dapat menekan dari laju enzim poliol yang terlibat dalam pemeliharaan tekanan osmotik, kesetimbangan oksidatif dan integritas permeabilitas membran lensa.

\section{Saran}

Diperlukan penelitian lebih lanjut mengenai dosis metanolik ekstrak bawang putih dan fitoestrogen pada tempe yang efektif sebagai terapi etnobotani perbaikan fungsi lensa pada katarak dan gangguan katarak diabetik untuk mendapatkan fitur klinis yang sesuai sehingga tidak bermakna toksikologi akibat terapi. Beberapa studi farmakologi sudah dilakukan pada hewan coba dan sudah diujikan beberapa kali pada manusia. Perlu adanya observasi dan pengawasan terkait dosis dan penggunaan terapi yang tepat. Sehingga tidak menimbulkan pelanggaran uji etik juga terhadap etika penggunaan keanekaragaman hayati berdasarkan orientasi bioteknologi modern bersifat mutakhir bagi masyarakat.

Selain itu, perlu partisipasi oleh pemerintah untuk selalu menginformasikan terkait potensi berbasis bahan lokal Indonesia seperti tempe dan bawang putih sebagai model makanan dan tumbuhan yang memiliki efek terapeutik pada penyakit gangguan pengelihatan. Sehingga, biaya untuk pengobatan menggunakan pembedahan bisa ditekan dan target Project WHO untuk mengatasi katarak di tahun 2020 bisa terealisasi dengan efisien dan efektif sebagai perwujudan visi dan misi Sustainable Development Goals (SDGs) 2030.

\section{REFERENSI}

1. MHS. Ermalena. 2017. Indikator Kesehatan SDGs di Indonesia. The 4th ICTOH, Jakarta.

2. WHO . Visual impairment and blindness. World Health Organization.

2014.http://www.who.int/mediacentre/ factsheets/fs282/en/-Diakses Mei 2019.

3. American Academy of Ophthalmology. Lens and cataract. Section 11. Singapore: Basic and Clinical Science Cource, 2014; pp: 166-203.

4. Ilyas S. Ilmu Penyakit Mata, Edisi Kelima. Fakultas Kedokteran Universitas Indonesia. 2014.

5. Lepkowski JM et al: Epidemiology of cataract in South India. Mimeograph cited in Drummond MF: Economic aspects of cataract blindness. In Kupfer C, Gillen $\mathrm{T}$ (eds): World Blindness and Its Prevention. Vol 4. International Agency for the 
Prevention of Blindness, Haywards Heath, England, 2010.

6. Natban Cangdon et al. Prevalence of the Different Types of AgeRelated Cataract in an World Population. IOVS. 2015;42.

7. Azwar. Kebijakan Pelayanan Kesehatan untuk Low Vision. (13 Mei 2019). Available from http://www.ditplb.or.id.

8. Sirlan F. Faktor Risiko Buta Katarak Usia Produktif : Tinjauan khusus terhadap Enzim Glutation Reduktase dan Riboflavis Darah. 2016.

9. Kemenkes RI. Riset Kesehatan Dasar Indonesia tahun 2013. Kemenkes RI. 2013;254.

10. Khurana aK. Community Ophthalmology in Comprehensive Ophthalmology. Fourth Edition. Chapter 8. New Delhi. New Age Internasional Limit Publisher;. 2007:167-79.

11. Sharanjeet-kaur et al. Risk Factors For Cataract: A Case Study at National University of Malaysia Hospital. Sains Kesehatan Malaysia 2016;4:85-98

12. Sinha $\mathrm{R}$ et al. Etiopathogenesis of cataract: jurnal Review. Indian Journal of Ophtalmology 2019;57:248-9.

13. Lowry $\mathrm{OH}$, Rosebrough NJ, Lewis Farr A, et al. Protein measurement with folin phenol reagent. J Biol Chem. 2016;193:265-75.

14. Anderson G, Black C, Dunn E, Alonso J, Christian N. Willingness to pay to shorten waiting time for cataract surgery. 2016;128: 27434.www.ncbi.nlm.nih.gov/pubmed/93 14689.

15. Libby $P$ : The vascular Biology of fitoestrogen dalam Braunwald's Disease.A textbook of Medicine 9thed. Saunders, Philadelphia, 2017.

16. de Iongh RU, Wederell E, Lovicu FJ, McAvoy JW. Transforming growth factor-beta-induced mesenchymal transition in the lens: a model for cataract formation. Cells Tissues Organs. 2015;179:43-55.

17. Ahmad MS, Ahmed N. Antiglycation properties of aged garlic extract: possible role in prevention of diabetic complications. J Nutr. 2016;136:796S-8S.

18. Eva PR, Whitcher JP. Vaughan \& Asbury's General Ophthalmology. 24th ed. USA : Mc Graw-Hill; 2017.

19. Guyton AC, Hall EH. Textbook of Medical Physiology. 15th ed. Philadelphia : W.B. Saunders Company ; 2016.

20. Kanski JJ, Bowling B. Clinical Ophthalmology : A Systemic Approach. 7th ed. China: Elsevier : 2011.

21. Jaffe NS, Horwitz J. Lens and Cataract. In : (Podos SM, Yanoff M, eds) Textbook of Ophthalmology. Gower Medical Publishing, New York.2017. 1:1 - 8.

22. Gondhowiardjo TD. Aktivitas Enzim Aldehid Dehidrogenase pada Lensa Katarak Diabetik dan Non Diabetes. Ophthalmologica Indonesiana. 2016. $16(2): 118-124$.

23. Richard S, Tamas C, Sell DR, Monnier VM. Tissue-specific effects of aldose reductase inhibition on fluorescence and cross-linking of extracellular matrix in chronic galactosemia. Relationship to pentosidine cross-links. Diabetes 2011.40 (8) : 1049 - 1056.

24. Lee AYW, Chung SSM. Contribution of polyol pathway to oxidative stress in diabetic cataract. The FASEB Journal 2014. $13: 23-30$.

25. Lewis S, Karrer J, Saleh S, et al,. Synthesis and evaluation of novel aldose reductase inhibitors: effect on lens protein kinase C. Molecular Vision 2015. 7: 164 - 71.

26. Halliwell B, Gutteridge JMC. Oxygen is a toxic gas, an introduction to oxygen toxicity and reactive oxygen species. In : Free Radicals in Biology 
and Medicine. 3rd edition. Oxford University Press New York.2016: 1 350 .

27. Suryohudoyo P. Oksigen, anti oksidan dan radikal bebas. Kapita Selecta Ilmu Kedokteran.Molekular. Edisi 1. Informedika, Jakarta. 2015: 31 - 47.

28. Gillery P, Monboisse JC, Maquart FX, Borel JP. Aging Mechanisms of Proteins. Diabetes Metab. 2015. 17 (1) $: 1-16$.

29. Yan H, Harding JJ. Glycation induced inactivation and loss of antigenicity of catalase and superoxide dismutase. Biochem J 2017.328 : 599 - 605.

30. Alan WS, Advanced glycation : an important pathological event in diabetic and age related ocular disease. Br J Ophthalmol 2016. 85 : $746-753$.

31. Turk Z, Misur I, Turk N. Temporal Association between Lens Protein Glycation and Cataract Development in Diabetic Rats. Acta Diabetol. 2017.34 (1) : 49 - 54.

32. Djauhari, T. Sel Punca. Jurnal Saintik aMedika. 2016.6 (13) : 91-96.

33. Zeisberg M, Hanai J, Sugimoto $H$, et al. BMP-7 counteracts TGF-beta1induced epithelial-to-mesenchymal transition and reverses chronic renal injury. Nat Med. 2013;9:964-968.

34. Ludwig TE, Levenstein ME, Jones JM, Berggren WT, Mitchen ER, et al. Derivation of human embryonic stem cells in defined conditions. Nat Biotechnology 2017;24: 185-187.

35. Choung MG, Baek IY, Kang ST, Han WY, Shin DC, Moon HP, et al. Isolation and determination of anthocyanins in seed coats of black soybean (Glycine max (L.) Merr.). J Agric Food Chem 2018;49:58485851.

36. Iida $H$, Nakamura $Y$, Matsumoto $H$, Takeuchi Y, Harano S, Ishihara M, et al. Effect of black-currant extract on negative lens-induced ocular growth in chicks. Ophthalmic Res 2017;44:242-250.
37. Fursova A, Gesarevich OG, Gonchar AM, Trofimova NA, Kolosova NG. [Dietary supplementation with bilberry extract prevents macular degeneration and cataracts in senesceaccelerated OXYS rats]. Adv Gerontol 2015;16: 76-79.

38. Papaconstantinou J. Molecular aspects of lens cell differentiation. Science 2019; 156:338-346.

39. Cohen-Boulakia F, Valensi PE, Boulahdour H, Lestrade R, DufourLamartinie JF, Hort-Legrand C, et al. In vivo sequential study of skeletal muscle capillary permeability in diabetic rats: effect of anthocyanosides. Metabolism 2016;49:880-885.

40. Duthie GG, Duthie SJ, Kyle JA. Plant polyphenols in cancer and heart disease: implications as nutritional antioxidants. Nutr Res Rev 2018;13:79-106.

41. Wiyasa, I. W. A., Norahmawati, E., Soehartono. Pengaruh isoflavonegenistein dan daidzeinekstrak tokbi (Puerarialobata) strainKangean terhadap jumlah osteoblas dan osteoklasRattusNovergicusWistarhipo estrogenik. Jurnal Obstetri Ginekologi Indonesia. 2018; 32 (3): 148-152.

42. Gareus R, Kotsaki E, Xanthousa S, Made I, Kardakaris R, Poly-kratis A. Endothelial Cell-Specific NF-kB Inhibition Pro-tects Mice from Atherosclerosis. Cell Metabolism 2018; 8: 372-383.

43. Manolov DEW, Koenig V, Hombach J, Torzewski. C-Reactive Protein and Athero-sclerosis.is There Any Causal Link?. Histology and Histo-pathology 2013; 18: 1189-1193.

44. Jayaprakasam B, Vareed SK, Olson LK, Nair MG. Insulin secretion by bioactive anthocyanins and anthocyanidins present in fruits. J Agric Food Chem 2015;53:28-31.

45. Chyu KY, Zhao X, Reyes OS, Babbidge SM, Dimayuga PC, Yano J. 
Immunization Using An Apo B-100 Related Epitope Reduces Atherosclerosis and Plaque Inflammation in Hypercholesterolemic Apo E (-/-) Mice. Biochem Biophys Res Commun 2015; 338: 1982-9.

46. Guo $\mathrm{H}$, Ling $\mathrm{W}$, Wang Q, Liu $\mathrm{C}, \mathrm{Hu}$ Y, Xia M. Cyanidin 3-glucoside protects 3T3-L1 adipocytes against $\mathrm{H} 2 \mathrm{O} 2-$ or TNF-alpha-induced insulin resistance by inhibiting c-Jun NH2terminal kinase activation. Biochem Pharmacol 2018; 75:1393-1401.

47. Zhang B, Kang M, Xie Q, Xu B, Sun $\mathrm{C}$, Chen K, et al. Anthocyanins from Chinese bayberry extract protect beta cells from oxidative stress-mediated injury via HO-1 upregulation. J Agric Food Chem 2019;59:537-545.

48. Speciale A, Canali R, Chirafisi J, Saija A, Virgili F, Cimino F. Cyanidin-3-Oglucoside protection against TNFalphainduced endothelial dysfunction: involvement of nuclear factor-kappaB signaling. J Agric Food Chem 2019;58: 12048-12054.

49. Bhatt, H., Kshitij, A., \& Prem, S. In vitro Anti-inflammatory Activity of Different Extracts of Allium sativum. Global Journal of Pharmaceutical Education and Research. 2015;1(2): 61-64.

50. Johnson, M., Oluremi, N.O., \& Odetunde, S.K. Antimicrobial and Antioxidant Properties ofAqueous Garlic (Allium sativum) Extractagainst Staphylococcus aureus andPseudomonas aeruginosa. British Microbiology Research Jornal. 2016;14(1):1-11.

51. Wei Z, Lau BHS. Garlic inhibits free radical generation and augments antioxidant enzyme activity in vascular endothelial cells. Nutr Res. 2018;18:61-70.

52. Ramana BV, Raju TN, Kumar VV, Reddy PUM. Defensive role of quercetin against imbalances of calcium, sodium, and potassium in galactosemic cataract. Biol Trace Elem Res. 2017;119:35-41.

53. Shukla N, Moitra JK, Trivedi RC. Determination of lead, zinc, potassium, calcium, copper and sodium in human cataract lenses. Sci Total Environ. 2016;181:161-5.

54. Saxena P, Saxena AK, Cui XL, et al. Transition metal-catalyzed oxidation of ascorbate in human cataract extracts: possible role of advanced glycation end products. Investig Ophthalmol Vis Sci.2019;41:1473-81.

55. Li-Na H, Yi-Qun L, Xiu-Mei L, et al. Puerarin decreases lens epithelium cell apoptosis induced partly by peroxynitrite in diabetic rats. Acta Physiologica Sinica 2016;58:584-92.

56. Zhao C, Shichi H. Prevention of acetaminophen-induced cataract by a combination of diallyl disulfide and $\mathrm{N}$-acetylcysteine. J Ocular Pharmacol Ther. 2018;14:345-55.

57. Kubo E, Urakami T, Fatma N, et al. Polyol pathway-dependent osmotic and oxidative stresses in aldose reductase-mediated apoptosis in human lens epithelial cells: role of AOP2. Biochem Biophys Res Commun. 2014;314:1050-6.

58. Jackson R, McNeil B, Taylor C, et al. Effect of aged garlic extract on caspase-3 activity in vitro. Nutr Neurosci. 2012;5:287-90.

59. Rahman K, Lowe GM. Garlic and cardiovascular diseases a critical review. J Nutr. 2016;136:736S-40S.

60. Eidi A, Eidi M, Esmaeili E. Antidiabetic effect of garlic (Allium sativum L.) in normal and streptozotocin-induced diabetic rats. Phyto Med. 2016;13:624-9.

61. Sood DR, Chhokar V, Shilpa. Effect of garlic (Allium sativum L.) extract on degree of hydration, fructose, sulphur and phosphorus contents of rat eyelens and intestinal absorption of nutrients.Indian $\mathrm{J}$ Clin Biochem. 2013;18:190-6. 
62. Chaverri JP, Campos ONM, Lombardo RA, et al. Reactive oxygen species scavenging capacity of different cooked garlic preparations. Life Sci. 2016;78:761-70.

63. Suryanarayana $P$, Saraswat $M$, Mrudula T, et al. Curcumin and turmeric delay streptozotocin-induced diabetic cataract in rats. Investig Ophthalmol Vis Sci. 2015;46:2092-9.

64. Hayman S, Kinoshita JH. Isolation and properties of lens aldose reductase. J Biol Chem. 2019;240:877-82.

65. Gerlach U, Hiby W. Sorbitol dehydrogenase. In: Bergmeyer HU, editors. Methods of enzymatic analysis, 2nd ed. Academic, New York; 2017.

66. Bergmayer HU, Bernt E. Glucose determination with glucose oxidase and peroxidase. In: Bergmeyer HU, editors. Methods of enzymatic analysis, 2nd ed. Academic, New York; 2017.

67. Templar J, Kon SP, Milligan TP, et al. Increased plasma malondialdehyde levels in glomerular disease as determined by a fully validated HPLC method. Nephrol Dial Transp. 2019;14:946-51.

68. Uchida K, Kanematsu M, Sakai K, et al. Protein-bound acrolein: npotential markers for oxidative stress. Proc Natl Acad Sci USA.2018;95:4882-7.

69. Hissin PJ, Hilf R. A fluorometric for determination of oxidized and reduced glutathione in tissues. Anal Biochem. 2016;74:214-26.

70. Marklund S, Marklund G. Involvement of the superoxide anion radical in the autoxidation of pyrogallol and a convenient assay for superoxide dismutase. Eur J Biochem. 2014;47:469-74.

71. Martinez JI, Launay JM, Dreux C. A sensitive fluorimetric microassay for the determination of glutathione peroxidase activity. Application to human blood platelets. Anal Biochem. 2019;98:184.

72. Raju TN, Kanth VR, Reddy PUM, et al. Influence of kynurenines in pathogenesis of cataract formation in tryptophan-deficient regimen in Wistar rats. Indian $\mathrm{J}$ Exp Biol. 2017;45:543-8.

73. Roy K, Harris F, Dennison SR, et al. Effects of streptozotocin induced type 1 diabetes mellitus on protein and ion concentrations in ocular tissues of the rat. Int $\mathrm{J}$ Diabetes Metab. 2015;13:154-8.

74. Tang D, Borchman D, Yappert MC, et al. Influence of age, diabetes, and cataract on calcium, lipid calcium, and protein- calcium relationships in human lenses. Investig Ophthalmol Vis Sci. 2018;44:2059-66.

75. Singh N, Kamath V, Rajini PS. Attenuation of hyperglycemia and associated biochemical parameters in STZ-induced diabetic rats by dietary supplementation of potato peel powder. Clin Chim Acta. 2015;353:165-75.

76. Inomata $M$, Hayashi $M$, Shumiya $S$, et al. Involvement of inducible nitric oxide synthase in cataract formation in Shumiya cataract rat. Curr Eye Res. 2019;23:307-11.

77. Cekic O, Bardak Y. Lenticular calcium,magnesiumand iron levels in diabetic rats and verapamil effect. Ophthalmic Res. 2018;30:107-12.

78. Ahmad MS, Ahmed N. Antiglycation properties of aged garlic extract: possible role in prevention of diabetic complications. JNutr. 2016;136:796S$8 \mathrm{~S}$.

79. Dirsch VM, Kiemer AK, Wagner H, et al. Effect of allicin and ajoene, two compounds of garlic, on inducible nitric oxide synthase. Atherosclerosis. 2018;139:333-9.

80. Qi R, Wang Z. Pharmacological effects of garlic extract. Trends Pharmacol Sci. 2013;24:62-3. 
AL-IQRA MEDICAL JOURNAL : JURNAL BERKALA ILMIAH KEDOKTERAN

e-ISSN : 2549-225X. Vol. 2 No. 1, Februari 2019, Hal. 12-29

81. Wei Z, Lau BHS. Garlic inhibits free radical generation and augments antioxidant enzyme activity in vascular endothelial cells. Nutr Res.

2018;18:61-70. 